\title{
Kombinasi Ekstrak Cymbopogon nardus L. dan Nicotiana tabacum Sebagai Insektisida Nabati Helopeltis antonii Sign.
}

\author{
Extract Combination of Cymbopogon nardus L. and Nicotiana tabacum as \\ Botanical Insecticides of Helopeltis antonii Sign.
}

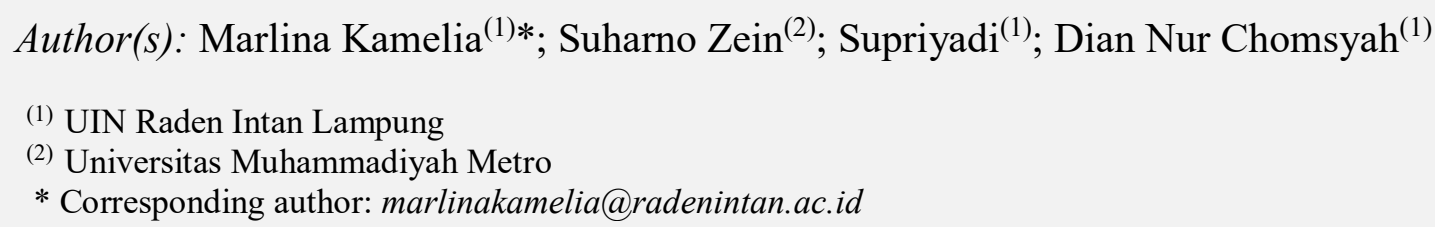

\begin{abstract}
ABSTRAK
Helopeltis antonii Sign. merupakan salah satu jenis serangga yang kerap menyerang tanaman kakao di Indonesia. Oleh karena itu perlu dicari alternatif insektisida yang lebih ecofriendly sehingga meminimalisir dampak buruk yang mungkin ditimbulkan akibat penggunaan jangka panjang. Insektisida nabati menjadi salah satu alternatif yang mungkin dapat digunakan. Cymbopogon nardus L. memiliki senyawa aktif sitronela sedangkan Nicotiana tabacum memiliki senyawa aktif nikotin yang keduanya berpotensi sebagai insektisida nabati dan bersifat biodegradable. Penelitian ini terdiri dari 5 perlakuan yaitu kontrol (P0), kombinasi C. nardus dan N. tabacum (80 $\mathrm{ml}$ dan $20 \mathrm{ml}(\mathrm{P} 1)$; $60 \mathrm{ml}$ dan $40 \mathrm{ml}(\mathrm{P} 2) ; 50 \mathrm{ml}$ dan $50 \mathrm{ml}(\mathrm{P} 3) ; 40 \mathrm{ml}$ dan $60 \mathrm{ml}$ (P4); serta $20 \mathrm{ml}$ dan 80 $\mathrm{ml}(\mathrm{P} 5))$. Hasil penelitian menunjukkan adanya pengaruh pemberian ekstrak C. nardus dan N. tabacum terhadap mortalitas $H$. antonii.P0 tingkat mortalitas 3,33\%; P1 sebesar 26,70\%; P2 sebesar 26,70\%; P3 sebesar 67\%, P4 sebesar 80\%, dan P5 sebesar 93,30\%. Hasil analisis ragam dengan ANOVA menunjukkan adanya pengaruh perlakuan dan hasil uji lanjut BNT menunjukkan pengaruh perlakuan terbaik adalah pada P5. Oleh karena itu dapat disimpulkan kombinasi ekstrak C. nardus dan $N$. tabacum efektif sebagai insektisida nabati untuk $H$. antonii.
\end{abstract}

\section{Kata Kunci:}

Cymbopogon nardus L.; Ecofriendly; Helopeltis antonii Sign.; Insektisida Nabati; Nicotiana tabacum.;

\section{Keywords:}

Botanical insecticide;

Cymbopogon nardus L.;

Ecofriendly;

Helopeltis antonii Sign.;

Nicotiana tabacum;

\section{ABSTRACT}

Helopeltis antonii Sign.is one type of insect that often attacks cocoa plants in Indonesia. Therefore, it is necessary to find alternative insecticides that are more ecofriendly to minimize the bad effects that may result from long-term use. Botanical insecticides are an alternative that might be used. Cymbopogon nardus L. has active compound citronella while Nicotiana tabacum has an active nicotine compound, both of which are potential as plant insecticides and are biodegradable. This study consisted of 5 treatments, namely control (P0), a combination of C. nardus and N. tabacum $(80 \mathrm{ml}$ and $20 \mathrm{ml}(\mathrm{Pl}) ; 60 \mathrm{ml}$ and $40 \mathrm{ml}$ (P2); $50 \mathrm{ml}$ and $50 \mathrm{ml}$ (P3); $40 \mathrm{ml}$. and $60 \mathrm{ml}$ (P4), and $20 \mathrm{ml}$ and $80 \mathrm{ml}$ (P5)). The results showed the effect of $\mathrm{C}$. nardus and $\mathrm{N}$. tabacum extracts on the mortality of $\mathrm{H}$. antonii. P0 mortality rate $3.33 \%$; P1 of $26.70 \%$; P2 of $26.70 \%$; P3 was $67 \%$, P4 was $80 \%$, and P5 was $93.30 \%$. The results of analysis of variance with ANOVA showed the effect of treatment and the results of the LSD test showed that the best treatment effect was at P5. Therefore, it can be concluded that the combination of C. nardus and $\mathrm{N}$. tabacum extracts is effective as a botanical insecticide for $\mathrm{H}$. antonii. 


\section{PENDAHULUAN}

Komoditas pertanian yang memiliki peran penting salah satunya adalah kakao (Theobroma cacao L.) Namun, ditemukan banyak kendala pada pertanian kakao di antaranya adalah serangan serangga hama Helopeltis antonii Sign. (Hemiptera: Miridae). Hama ini menyerang bagian pucuk yang muda, tunas serta bunga dan buah baik yang muda maupun matang. $H$. antonii merusak dengan cara menusukkan stilet kemudian menghisap cairan sel yang disertai pengeluaran cairan bersifat racun yang memicu kematian tanaman dalam kasus yang berat (Utami et al., 2017)

Petani selama ini masih banyak menggunakan insektisida sintetik yang tidak ramah lingkungan. Timbulnya kesadaran akan bahaya pemakaian bahan kimia sintetis dalam pertanian menjadikan pertanian organik menarik perhatian baik di tingkat produsen maupun konsumen. Konsumen umumnya akan memilih bahan pangan yang aman bagi kesehatan dan ramah lingkungan. Hal ini mendorong meningkatnya penelitian untuk mencari insektisida alternatif yang lebih ecofriendly sehingga meminimalisir dampak buruk yang mungkin ditimbulkan akibat penggunaan jangka panjang. Insektisida nabati menjadi salah satu alternatif yang mungkin dapat digunakan (Mayrowani, 2016).

Cymbopogon nardus L. memiliki senyawa aktif sitronela yang tidak disukai nyamuk dan beberapa serangga lainnya sehingga sering digunakan sebagai insektisida nabati untuk mengendalikan hama tanaman. Adapun senyawa aktif lain yang dikandungnya yaitu dipentena, farnesol, geraniol, mirsena, metil heptenol, nerol, dan sitral. Kandungan senyawa aktif tanaman $C$. nardus dapat mengendalikan hama tanaman seperti kutu tanaman, beberapa serangga (Tribolium sp.; Sitophilus sp.; Calloso bruchus sp.); jenis Nematoda seperti
Meloidogyne sp.; dan Jamur Pseudomonas sp. (Arfianto, 2018).

Nicotiana tabacum memiliki senyawa aktif nikotin. Nikotin merupakan bahan yang dapat dipergunakan untuk fungisida alami atau insektisida nabati. Nikotin dapat berperan sebagai racun kontak untuk mengendalikan beberapa jenis ulat perusak daun, serangga penghisap, maupun jamur. Konsentrasi nikotin paling tinggi berada di daun dan ditemukan juga di batang tetapi lebih sedikit jumlahnya (Assagaf \& Masrikhan, 2018).

Berdasarkan latar belakang di atas maka keduanya berpotensi sebagai insektisida nabati dan bersifat biodegradable. Oleh karena itu tujuan penelitian ini adalah untuk mengetahui pengaruh kombinasi ekstrak $C$. nardus dan $N$. tabacum terhadap mortalitas $H$. antonii Sign.

\section{METODOLOGI}

Penelitian ini dilaksanakan pada perkebunan kakao di Desa Wiyono Kecamatan Gedong Tataan Kabupaten Pesawaran Provinsi Lampung. Jenis penelitian ini adalah eksperimental kuantitatif yang dirancang dengan Rancangan Acak Lengkap (RAL) menggunakan 5 perlakuan. Ekstrak $C$. nardus dibuat dengan cara menimbang sebanyak 250 g C. nardus kering lalu dicacah dan direndam dengan air $8 \mathrm{~L}$ selama 1 malam lalu disaring. Hal yang sama juga dilakukan pada N. tabacum, baru kemudian kedua ekstrak tersebut diaplikasikan pada penenelitian dengan kombinasi sebagai berikut :

1. P0 : $100 \mathrm{ml}$ air (kontrol negatif)

2. P1 : Kombinasi $C$. nardus dan $N$. tabacum $80 \mathrm{ml}$ dan $20 \mathrm{ml}$

3. P2 : Kombinasi $C$. nardus dan $N$. tabacum $60 \mathrm{ml}$ dan $40 \mathrm{ml}$

4. P3 : Kombinasi $C$. nardus dan $N$. tabacum $50 \mathrm{ml}$ dan $50 \mathrm{ml}$ 
5. P4 : Kombinasi C. nardus dan $N$. tabacum $40 \mathrm{ml}$ dan $60 \mathrm{ml}$

6. P5: Kombinasi C. nardus dan $N$. tabacum $20 \mathrm{ml}$ dan $80 \mathrm{ml}$

Tiap-tiap perlakuan diulang sebanyak 3 kali ulangan dengan hewan uji sebanyak 10 ekor nimfa $H$. antonii Sign. instar IV. Nimfa instar III dipilih karena merupakan fase yang memiliki aktivitas makan paling tinggi.

Uji efektivitas kombinasi ekstrak dilakukan dengan mencelupkan buah kakao ukuran sedang ke dalam ekstrak sesuai konsentrasi tiap perlakuan selama 30 menit. Buah kakao kemudian dibiarkan hingga mengering kemudian dimasukkan dalam tabung uji. Nimfa $H$. antonii kemudian dimasukkan juga ke dalam masing-masing tabung tersebut.

Parameter yang diamati yaitu mortalitas nimfa $H$. antonii setiap jam selama 4 jam. Data yang didapatkan kemudian dianalis dengan ANOVA untuk mengetahui apakah ada pengaruh perlakuan. Bila ada pengaruh perlakuan dilakukan uji lanjut BNT pada taraf kepercayaan 95\% untuk mengetahui perlakuan mana yang paling berpengaruh.

\section{HASIL DAN PEMBAHASAN}

Berdasarkan hasil uji kualitatif fitokimia menunjukkan bahwa terkandung metabolit sekunder di dalam ekstrak $C$. nardus L. dan N. tabacum. Uji kualitatif metabolit sekunder yang dilakukan meliputi uji fenolik, steroid, triterpenoid, alkaloid, tannin, flavonoid, dan saponin. Pengujian dilakukan secara kualitatif sehingga hasilnya didasarkan pada perubahan yang terjadi pada setiap hasil akhir pengujian. Adapun senyawa metabolit sekunder yang terdapat di dalam ekstrak tersebut tampak pada Tabel 1 berikut ini :

Tabel 1. Uji Kualitatif Fitokimia

Table 1. Phytochemical Qualitative Test

\begin{tabular}{llccl}
\hline $\begin{array}{c}\text { Uji Kualitatif } \\
\text { Fitokimia } \\
\text { Qualitative } \\
\begin{array}{c}\text { Phytochemical } \\
\text { Test }\end{array}\end{array}$ & \multicolumn{1}{c}{$\begin{array}{c}\text { Reagen } \\
\text { Reagent }\end{array}$} & $\begin{array}{c}\text { Cymbopo } \\
\text { gon } \\
\text { nardus L. }\end{array}$ & $\begin{array}{c}\text { Nicotiana } \\
\text { tabacum }\end{array}$ & $\begin{array}{c}\text { Ket. }(+) \\
\text { Inf. }(+)\end{array}$ \\
\hline Fenolik & MgCl3 & & & \\
Steroid & Uji Liebermann-Burchard & - & + & Coklat Kehitaman \\
Triterpenoid & Uji Liebermann-Burchard & + & + & Hijau \\
Alkaloid & Meyer & + & + & Merah Muda/Ungu \\
Tanin & FeCl3 & + & + & Endapan Coklat \\
Flavonoid & 0,5 mg dan HCl & - & - & Merah Muda \\
Saponin & Pengocokan & - & - & Busa \\
\hline
\end{tabular}

Keterangan. : (+): terkandung metabolit sekunder

$(-)$ : tidak terdapat metabolit sekunder

Notes

: (+): contained secondary metabolites

(-) : no secondary metabolites

Tabel 1 menunjukkan bahwa $C$. nardus L. memiliki kandungan senyawa metabolit sekunder berupa fenolik, triterpenoid, alkaloid, Dan tanin. Sedangkan, senyawa metabolit sekunder yang terkandung di dalam $N$. tabacum adalah fenolik, steroid, triterpenoid, alkaloid, dan tanin.

Ekstrak yang telah diuji fitokimia selanjutnya digunakan sebagai bahan uji insektisida nabati untuk nimfa $H$. antonii Sign. Jumlah kematian nimfa tampak pada Tabel 2 berikut : 
Tabel 2. Jumlah Kematian Nimfa $H$. antonii

Table 2. Number of Deaths of H. antonii nymphs

\begin{tabular}{ccccc}
\hline \multirow{2}{*}{$\begin{array}{c}\text { Perlakuan } \\
\text { Treatments }\end{array}$} & \multicolumn{3}{c}{$\begin{array}{c}\text { Jumlah Kematian Serangga Uji } \\
\text { Number of Dead Insects tested }\end{array}$} & \multirow{2}{*}{$\begin{array}{c}\text { Rata-rata } \\
\text { Mean }\end{array}$} \\
\cline { 2 - 4 } & U1 & U2 & U3 & \\
\hline P0 & 1 & 0 & 0 & 0,33 \\
P1 & 3 & 2 & 3 & 2,67 \\
P2 & 3 & 2 & 3 & 2,67 \\
P3 & 6 & 7 & 7 & 6,67 \\
P4 & 9 & 7 & 8 & 8 \\
P5 & 9 & 9 & 10 & 9,33 \\
\hline
\end{tabular}

Keterangan : $\mathrm{U}=$ Ulangan

Notes $\quad: \mathrm{U}=$ Repetition

Jumlah rata-rata kematian nimfa terendah ditunjukkan oleh P0 yaitu kurang dari 1 ekor dan hanya terdapat pada ulangan 1 yang mungkin disebabkan oleh serangga stres atau faktor lainnya karena pada perlakuan ini sama sekali tidak diberikan ekstrak. Jumlah rata-rata kematian serangga tertinggi yaitu pada perlakuan P5 sebanyak 9,33 ekor. Persentase mortalitas nimfa uji selanjutnya ditunjukkan oleh gambar 1 di bawah ini :

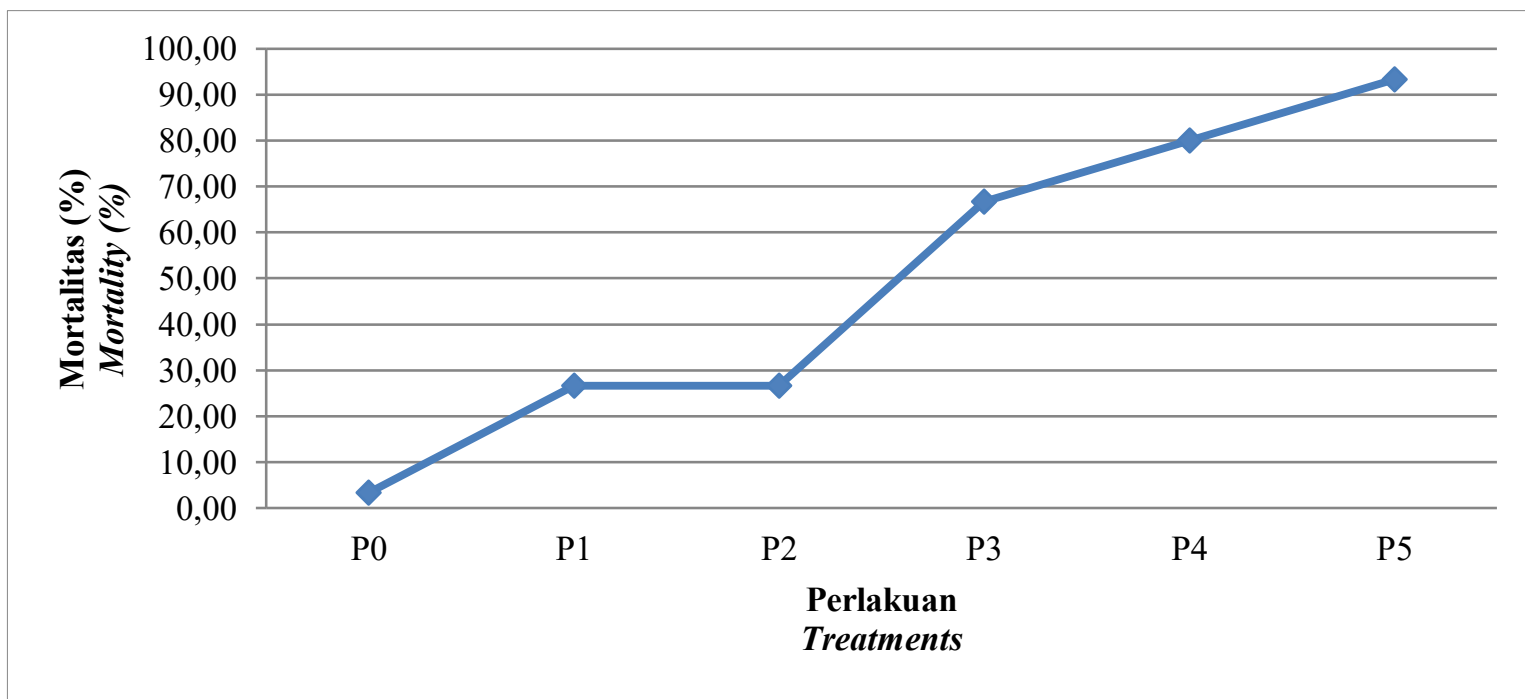

Gambar 1. Persentase Kematian Nimfa

Figure 1. Percentage of Nymph Deaths

Gambar di atas menunjukkan bahwa persentase kematian nimfa mengalami peningkatan. Persentase terendah sebesar $3,33 \%$ pada P0 sedangkan persentase terbesar pada P5 sebesar 93,33\%.

Data yang telah diperoleh kemudian dianalis menggunakan ANOVA dan diperoleh nilai signifikansi sebesar 0,00 yang artinya terdapat pengaruh perlakuan sehingga dilanjutkan dengan uji lanjut BNT untuk melihat perlakuan mana yang paling berpengaruh. Hasil uji BNT pada tingkat kepercayaan 95\% tampak pada Tabel 3 berikut ini : 
Tabel 3. Pengaruh Pemberian Ekstrak Terhadap Persentase Kematian Nimfa

Table 3. The Effect of Extracts application on the Percentage of Nymph Deaths

\begin{tabular}{cc}
\hline Perlakuan & Persentase Kematian Nimfa (\%) \\
Treatment & Percentage of Nymph Mortality (\%) \\
\hline P0 & $3,33^{\mathrm{a}} \pm 3,33$ \\
P1 & $26,67^{\mathrm{b}} \pm 3,33$ \\
P2 & $26,67^{\mathrm{b} \pm} 3,33$ \\
P3 & $66,67^{\mathrm{c}} \pm 3,33$ \\
P4 & $80,00^{\mathrm{cd}} \pm 3,33$ \\
P5 & $93,33^{\mathrm{d}} \pm 3,33$
\end{tabular}

Keterangan : Perlakuan yang diikuti huruf yang sama menunjukkan tidak berbeda nyata pada uji BNT taraf $5 \%$ Notes : Treatment followed by the same letter showed no significant difference based on Fisher's LSD test at $5 \%$ level

Hasil uji BNT menunjukkan perlakuan yang paling berpengaruh adalah P5. Perlakuaan P0 berbeda nyata dengan semua perlakuan, begitu pula dengan perlakuan P1. Namun, perlakuan P2 dan P3 tidak menunjukkan perbedaan yang nyata antar keduanya namun berbeda nyata dengan perlakuan lainnya. P3 dan P4 tidak berbeda nyata antar keduanya tetapi P4 juga tidak berbeda nyata pengaruhnya dengan P5.

Berdasarkan data-data yang telah dipaparkan di atas kombinasi ekstrak $C$. nardus L. dan N. tabacum yang bertujuan untuk mengatasi hama $H$. antonii Sign. khususnya fase nimfa memberikan pengaruh signifikan. Fase nimfa dipilih karena paling peka terhadap insektisida racun kontak sesaat setelah ganti kulit dan ketahanannya meningkat seiring bertambahnya usia kemudian menurun kembali saat menjelang ganti kulit (Hadi, 2006).

Senyawa aktif pada $C$. nardus $\mathrm{L}$. adalah sitronela sedangkan pada $N$. tabacum adalah nikotin. Kombinasi ekstrak menyebabkan perbedaan kandungan sitronela dan nikotin pada setiap perlakuan. Kandungan sitronela yang semakin kecil seiring dengan peningkatan kandungan nikotin maka mortalitas nimfa $H$. antonii Sign. semakin besar. Hal ini tampak pada hasil penelitian pada perlakuan P5 yang efektif memicu kematian nimfa $H$. antonii Sign.
Insektisida berbahan aktif sitronela tergolong racun kontak dan racun perut (Una \& Wahyuni, 2019). Insektisida yang tergolong racun kontak akan masuk ke dalam tubuh serangga sasaran lewat kulit (kutikula), trakea, atau kelenjar sensorik dan organ lain yang berhubungan dengan kutikula (Anamah, 2017). Senyawa aktif yang terkandung di dalam insektisida nabati akan melarutkan lemak atau lapisan lilin pada kutikula sehingga menyebabkan bahan aktif tersebut bisa menembus tubuh serangga (Ariani et al., 2019). Sitronela akan bekerja dengan cara menghambat enzim asetil kolinesterase sehingga terjadi fosforilasi asam amino serin pada pusat asteratik enzim tersebut. Gejala keracunan timbul karena adanya penimbunan asetilkolin yang ditandai dengan munculnya gangguan sistem syaraf motorik, kejang, kelumpuhan pernafasan hingga menyebabkan kematian (Laba, 2013).

Insektisida yang bekerja sebagai racun perut adalah insektisida yang membunuh serangga sasaran jika termakan dan masuk ke dalam organ pencernaan. Insektisida akan diserap dinding saluran pencernaan makanan kemudian dibawa oleh cairan tubuh ke organ target seperti sistem syaraf pusat serangga, organ-organ respirasi, lambung, dan sebagainya (Sartika, 2018).

C. nardus $\mathrm{L}$. selain mengandung sitronela juga mengandung metabolit 
sekunder tanin yang bersifat sebagai racun kontak dan antifeedant. Tanin akan bereaksi dengan protein yang menyebabkan penghambatan kerja enzim protease sehingga tidak dapat larut dalam air. Hal ini menyebabkan protein lebih sulit dicapai oleh cairan pencernaan sehingga berpengaruh terhadap sistem pencernaan dan dapat menurunkan laju pertumbuhan, kehilangan berat badan dan gejala gangguan pada penyerapan nutrisi (Liansyah et al., 2018).

$N$. tabacum mengandung nikotin tergolong racun kontak dan racun syaraf. Racun kontak akan masuk ke dalam tubuh serangga melalui kulit menembus kutikula, trakea, atau organ lain yang berhubungan dengan kutikula. Bahan aktif yang telah menembus kutikula selanjutnya akan merusak sistem syaraf yang bekerja dengan cara menghambat akson pada kanal ion sehingga terjadi potensial aksi terus menerus (Aji et al., 2015). Nikotin mengikat protein voltage gate sodium channel (VGSC) yang mengatur impuls syaraf. Hal ini mengakibatkan impuls syaraf akan mengalami stimulasi secara terus menerus sehingga serangga mengalami hiper eksitasi (kegelisahan) dan konvulsi (kekejangan). Nikotin mampu membunuh $H$. antonii dengan cepat karena nikotin merupakan racun syaraf yang dapat bereaksi sangat cepat. Alkaloid nikotin, sulfat nikotin dan kandungan nikotin lainnya dapat digunakan sebagai racun kontak, fumigan dan racun perut. Secara umum gejala-gajala keracunan nikotin secara berurutan adalah rangsangan, kejang-kejang, cacat, hingga kematian (Hasanah et al., 2012).

Hasil pengamatan perilaku serangga uji nimfa $H$. antonii Sign. yang dikontakkan dengan insektisida menunjukkan gejala awal adalah gerakan berjalan lambat pada permukaan buah kakao. Adapun gejala keracunan yang teramati adalah nimfa kemudian menjadi kaku (kejang), menggelepar, lumpuh, dan akhirnya mati. Pada penelitian ini juga tampak bahwa konsentrasi nikotin yang semakin tinggi tingkat kematian (mortalitas) nimfa uji juga semakin meningkat.

Pada perlakuan P1 dan P2 mortalitas nimfa tidak menunjukkan perbedaan yang signifikan karena konsentrasi sitronela lebih bear dibandingkan nikotin sehingga daya racun perutnya lebih kuat dibandingkan racun syaraf. Namun, pada perlakuan P3, P4, dan P5 mampu memicu kematian $H$. antonii Sign. dengan persentase kisaran 66,67\% hingga 93,33\%. Hal ini menunjukkan bahwa perlakuan ini memenuhi kriteria efikasi sebagai insektisida yang efektif menekan populasi nimfa di atas 50\%.

Senyawa metabolit sekunder yang terkandung dalam ekstrak juga turut serta membantu meningkatkan mortalitas nimfa $H$. antonii Sign. dengan cara menghambat permeabilitas membran, mengganggu sintesis protein, serta menghambat kerja enzim. Senyawa metabolit sekunder yang menghambat permeabilitas membran adalah senyawa fenolik. Tanin mampu memicu denaturasi protein serta menghambat kerja enzim (Liansyah et al., 2018).

\section{KESIMPULAN}

Berdasarkan hasil penelitian yang telah dilakukan dapat disimpulkan bahwa kombinasi ekstrak $C$. nardus L. dan $N$. tabacum berpengaruh nyata terhadap mortalitas nimfa $H$. antonii dengan tingkat persentase kematian tertinggi sebesar 93,33\%.

Saran untuk penelitian selanjutnya dapat dilakukan uji coba langsung ke tanaman kakao yang terserang hama $H$. antonii.

\section{DAFTAR PUSTAKA}

Aji, A., Maulinda, L., \& Amin, S. (2015). Isolasi Nikotin Dari Puntung Rokok Sebagai Insektisida. Jurnal 
Teknologi Kimia Unimal, 4(1), 100 120.

Anamah, F. (2017). Efektivitas Air 尌 Perasan Jeruk Nipis (Citrus aurantifolia) Terhadap Kematian Larva Aedes sp [Universitas Muhammadiyah Semarang].

Arfianto, F. (2018). Pengendalian Hama

Kutu Putih (Bemisa Tabaci) pada Buah Sirsak dengan Menggunakan Pestisida Nabati Ektrak Serai (Cymbopogon Nardus L.). Daun: Jurnal Ilmiah Pertanian Dan Kehutanan, 5(1), 17-26.

Ariani, N. N., Purwanti, E., Rahardjanto, E. A., Fatmawati, D., \& Permana, F. H. (2019). Efektivitas Limbah Puntung Rokok dan Ekstrak Daun Pacar Cina (Aglaia odorata Lour.) Sebagai Insektisida Ulat Grayak (Spodoptera litura Fabricius.) Pada Saei Secara In Vitro. In I. Hindun, A. Rahardjanto, A. M. Hudha, M. A. K. Budiyanto, A. Fauzi, Husamah, \& M. M. Nuryady (Eds.), Prosiding Seminar V 2019 "Peran Pendidikan dalam Konservasi dan Pengelolaan Lingkungan Berkelanjutan ." Penerbit Kota Tua.

Assagaf, M. K., \& Masrikhan. (2018). 的 Tombi ( waste of tobacco stem as multi-biopesticide and blue industry ): Studi Kelayakan Limbah Batang Tembakau Sebagai Multi-pestisida Nabati dan Blue Industry di Kabupaten Temanggung Sebagai Wujud Manifestasi Surat Ali Imron : 190-191. In I. Zulkarnain, M. W. Musthofa, I. Kuswidi, I. Fajriati, D. A. Kurniawati, F. A. Rakhmadi, Nurochman, D. I. Pramesti, \& Kardimin (Eds.), Prosiding Konferensi Integrasi Interkoneksi Islam dan Sains (Vol. 1, Issue
September, pp. 129-138). Fakultas Sains \& Teknologi, Universitas Islam Negeri Sunan Kalijaga Yogyakarta.

Hadi, U. K. (2006). Bioekologi Berbagai 理 Jenis Serangga Pengganggu Pada Hewan Ternak Di Indonesia dan Pengendaliannya.

Hasanah, M., Tangkas, I., \& Sakung, J. (2012). Daya Insektisida Alami Kombinasi Perasan Umbi Gadung (Dioscorea hispida Dennst ) dan Ekstrak Tembakau ( Nicotiana tabacum L). Jurnal Akademika Kimia, 1(4), 224186.

Laba, I. W. (2013). Efektivitas Insektisida E Minyak Serai Wangi dan Cengkeh Terhadap Hama Penghisap Buah Lada ( Dasynus piperis China ) Effectivity of lemon grass and clove oil insecticides to pepper bug ( Dasynus piperis China ). Buletin Penelitian Tanaman Rempah Dan Obat, 24(1), 26-34.

Liansyah, N., Hasnah, H., \& Rusdy, A. E (2018). Pengaruh Campuran Ekstrak Kulit Bakau dan Serai Wangi Terhadap Mortalitas dan Perkembangan Crocidolomia pavonana (F). Jurnal Ilmiah Mahasiswa Pertanian, 3(4), 7-15.

Mayrowani, H. (2016). Pengembangan EQ Pertanian Organik di Indonesia. Forum Penelitian Agro Ekonomi, 30(2), 91-108.

Sartika, S. (2018). Hubungan Kadar Hemoglobin Dengan Jumlah Eritrosit Pada Petani Yang Terpapar Pestisida Di Desa Klampok Kabupaten Brebes [Universitas Muhammadiyah Semarang]. 
Una, S. S., \& Wahyuni, S. (2019).

EO Aktivitas Formulasi Pestisida Nabati pada Siput Setengah Telanjang Parmarion martensi (Gastropoda: Ariophantidae). AGRICA, 12(1), 111.

Utami, A., Dadang, D., Nurmansyah, A., \& Laba, I. W. (2017). Tingkat Resistensi Helopeltis antonii (Hemiptera: Miridae) pada Tanaman Kakao terhadap Tiga Golongan Insektisida Sintetis. Jurnal Tanaman Industri Dan Penyegar, 4(2), 89. 